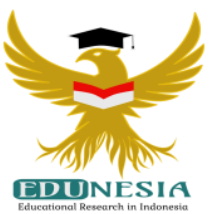

\title{
Full Day School Management at SMA As Safi'iyah Medan
}

\author{
Ojak Manurung1; Candra Wijaya ${ }^{2}$; Achmad Zulfikar Siregar ${ }^{3}$ \\ 1,2,3 Department of Education Management, Universitas Islam Negeri Sumatera Utara, Indonesia \\ ${ }^{1}$ Corresponding Email: manurungojak34@gmail.com, Phone Number: 0823 xxxx xxxx
}

\author{
Article History: \\ Received: Dec 11, 2021 \\ Revised: Jan 08, 2022 \\ Accepted: Jan 13, 2022 \\ Online First: Jan 15, 2022
}

\section{Keywords:}

Full Day School,

School Management,

SMA As Safi'iyah.

\section{Kata Kunci:}

Full Day School, Managemen Sekolah, SMA As Safi'iyah.

\section{How to cite:}

Manurung, O., Wijaya, C., \& Siregar. A.Z. (2022). Full Day Management at SMA As Safi'iyah Medan. Edunesia: Jurnal Ilmiah Pendidikan, 3 (1): 89-98.

This is an open access article under the $C C-B Y-N C$-ND license

\begin{abstract}
This study aims to determine Full Day School Management in SMA As Syafi'iyah Medan, Jl. Karya Wisata Ii No.1,Medan Johor, Medan, North Sumatra Province. This research is a qualitative popoulasi study of the Full Day School teacher and management and students of SMA As Syafi'iyah Medan. In an effort to improve student character education in MAN 2, the terrain model includes stages, namely: planning Full Day School learning, implementing Full Day School learning and evaluating Full Day School learning. Learning planning is adapted to the curriculum adopted by SMA As Syafi'iyah Medan, namely the government curriculum, local curriculum and school curriculum and the formulation of syllabus and plan for implementing learning. The implementation of Full Day School learning consists of habituation activities, exemplary activities, nationalism and patriotism activities and student creativity activities. Evaluation Full Day School learning in general in Medan Model 2 MAN 2 in determining minimal completeness provides an assessment of three domains, namely cognitive, affective and domain psychomotor.
\end{abstract}

\begin{abstract}
Abstrak: Penelitian ini bertujuan untuk mengetahui Manajemen Full Day School di SMA As Syafi' iyah Medan, Jl. Karya Wisata Ii No.1, Kecamatan Medan Johor, Medan, Provinsi Sumatera Utara. Penelitian ini merupakan penelitian kualitatif popoulasi penelitian ini adalah guru Full Day School dan manajemen serta siswa-siswi SMA As Syafi'iyah Medan. Sebagai upaya meningkatkan pendidikan karakter siswa di SMA As Syafi'iyah Medan meliputi tahapan, yaitu : perencanaan pembelajaran Full Day School, pelaksanaan pembelajaran Full Day School dan evaluasi pembelajaran Full Day School. Perencanaan pembelajaran disesuaikan dengan kurikulum yang dianut SMA As Syafi'iyah Medan, yaitu kurikulum pemerintah, kurikulum local dan kurikulum sekolah dan penyusunan berupa silabus dan rencana pelaksanaan pembelajaran (RPP). Pelaksanaan pembelajaran Full Day School terdiri dari kegiatan pembiasaan, kegiatan keteladanan, kegiatan nasionalisme dan patriotism serta kegiatan kreatifitas siswa. Evaluasi Pembelajaran Full Day School secara umum SMA As Syafi'iyah Medan dalam menentukan ketuntasan minimal memberikan penilaian tiga ranah, yaitu ranah kognitif, ranah afektif dan ranah psikomotorik
\end{abstract}




\section{A. Introduction}

Educational management applied in the internal environment of the school system is only part of the principal's responsibility as education manager (Khori, 2016). Education managers (principals, heads of education offices, heads of offices of the ministry of religion) as modern executives must be able to observe and respond to all challenges posed by the external environment, both near and far. The immediate external environment is an environment that has a direct influence on the operations of educational institutions, such as various potentials and conditions in the field of education that become the concentration of the school's business itself, competitive situations, educational customer situations, and graduate users (Umam, 2017; Khori, 2016). All of them affect the determination of strategies that are expected to support the school in achieving its goals. The distant external environment is a variety of forces and conditions that arise outside the immediate external environment, including socio-economic, political, national security, technological developments, and global challenges (Fahmi, 2019). Indirectly affect the implementation of the education system in a school. Strategic management is a dynamic process because it takes place continuously in an organization. In other words, strategic management is intended so that the organization becomes a unit that is able to display high performance because a successful organization is an organization whose level of effectiveness and productivity is getting higher and higher (Widiyanto, 2016).

Internal and external environmental factors need to be considered, monitored, assessed, and included in executive decision making (Sari et al, 2017). Decision makers, including heads and other education managers, are often forced to carry out internal and external activities of educational institutions in order to serve various interests such as routine affairs, service, work must always be under the instructions or work guidelines set by the organization without considering the external needs of the organization concerned. constantly changing, so that the decision-making process is often not optimal in producing strategic decisions. The results of the actual problems faced by educational institutions cannot be resolved optimally (Bahri, 2019).

The world of Islamic education in Indonesia today is facing various tough challenges. Among these challenges are globalization in the fields of culture, ethics and morals, as a result of technological advances (transportation and information), and the low level of social capital, the low quality of education in Indonesia, and macro-national problems, which involve multidimensional crises in both the economic and social fields, politics, morals, culture and so on (Maya, 2017).

Various ideas and actions have been taken to resolve the various problems and failures above, such as the actualization of schools, leading Islamic schools, and Islamic education with an integrated system. The implementation of education with an integrated system has been running optimally in recent years and is in demand by the public, where this integrated system requires additional learning time, so it is commonly known as now with the term model school or Full Day School program, namely full day school.

At present, new strategies have begun to emerge to answer the problems above, for example the existence of a local initiative to improve the situation, namely the Full Day School Program which has been widely implemented by private schools in various cities in Indonesia (Wicaksnono, 2018). In the end, this school was able to become an elite school or favorite school with better quality education than public schools. 
In addition, there are indications that the world of Islamic education is experiencing failure, namely failing to humanize humans, failing to shape humans according to the vision and mission of their creation. This failure has implications for the materialistic education process, far from Islamic values and has a weak character (Ismail, 2016).

Islamic education inevitably has to be involved and play a role in overcoming and resolving the various challenges and failures mentioned above. It's just that the Islamic education system first evaluates and then re-actualizes and repositions even in the field of Islamic education, by synchronizing and collaborating with National Education policies to free the various challenges and failures above.

The root of the problem above lies in the materialistic education system coupled with a capitalistic economy, hedonistic culture, opportunistic politics, and individualistic social order, all of which are based on secularism, far from religious values. So that there is a need for repositioning, and re-actualizing the Islamic education system, both paragdimatically, conceptually and in application (Subaidi, 2014; Primarni, 2016).

Various ideas and actions have been taken to resolve the various problems and failures above, such as the realization of schools, leading Islamic schools, and Islamic education with an integrated system. The implementation of education with an integrated system has been running optimally in the past few years and is in demand by the community, where this integrated system requires additional learning time, so it is commonly known today as a model school or Full Day School program, namely a full day school.

At present, new strategies have begun to emerge to answer the problems above, for example the existence of a local initiative to improve the situation, namely the Full Day School Program which has been widely implemented by private schools in various cities in Indonesia. In the end, this school was able to become an elite school or favorite school with better quality education than public schools.

The Full Day School learning system is one of the creations and innovations of learning to create a superior, innovative and creative school with an integrated learning system based on faith and piety, as well as science and technology. The beginning of the implementation of this learning system is due to the increasing number of single-parents and the number of parent career activities, as well as the fact that most students spend most of their free time outside the home and use it for activities that are not useful. This is an indicator of problems that arise to immediately find alternative solutions. This condition makes education experts think hard to formulate a new paradigm of education in the context of optimizing free time with positive activities.

The Full Day School program has recently begun to grow rapidly in various schools, and has even become a trend as a quality school. Some schools have actually implemented this system as it should be. In it, the school equips itself with various facilities and programs (content) in such a way, so that the atmosphere makes children feel enjoy being at school, without having to lose time to play. However, there are also schools that only implement this program as a trend and prestige, moreover they only follow the program launched by the government, without paying attention to the readiness of the various components in the school.

The management of the Full Day School model in the teaching and learning process in schools is very precise and effective in giving birth to students who have complete personalities (integrated between general knowledge, Islamic insight and Islamic character), because children at elementary school age are in the operational-concrete phase and 
operational phase. - formal, there are objective facts that are conducive to educating and directing their whole personality.

One of the reasons why parents see the Full Day School program as a new strategy, by not giving homework to students, because they have been studying from morning to evening. Along with today's developments, many schools and madrasas are competing to improve their academic quality due to competitive demands and encouragement from the government with all their programs and financial assistance. From this factor, there are several public schools under the Ministry of National Education which have started to climb up to improve themselves so that they become more qualified than in previous years.

The integrated education system is run with the integration of several elements, namely: first, integrating the mode of education in the family and community within the school environment. The school is designed as a small Islamic environment through a boarding school program for MTs/MA or Full Day School for MA. Second, integrating the cognitive, affective and psychomotor domains. Third, integrating general education (national) with Islamic education. Fourth, combining the classical learning process with the surrounding environment, both mosques, laboratories, and the like. Fifth, combining the process of mastering the science of life with tsaqafah Islamiyah and the formation of syakhsyiyah Islamiyah.

several elements of the integrated education system above, there are several elements that have been applied in the education system in Indonesia today. The model school, the Full Day School program, is more accurately characterized by the first element in the integrated education system above, although in practice it is still related to several other elements. So it can be assumed that the expectation of the Full Day School model is the formation of a complete and integrated personality in students, meaning that there is integrity between the science of life (general) and tsaqafah Islamiyah and is equipped with an Islamic personality (character). At least it is hoped that Full Day School can be an alternative solution in solving various problems, challenges, failures of National Education and Islamic education in Indonesia today.

The application of the full day school model in this study was carried out during the full day teaching and learning process in elementary schools, from 06.45 to 15.00. The teaching and learning process is a two-way knowledge transfer process. In the teaching and learning process there are two different activities, namely teacher teaching and student learning, where these two activities are very different. The existence of a full day school model provides more time in the teaching and learning process, so that teachers can be more innovative and creative in teaching, and students also have more time to study, worship and interact socially in the school environment.

\section{B. Method}

The method used in this research is descriptive qualitative. With the aim of describing the phenomena that occur in the field as they are, then conclusions are drawn in order to obtain a theory and are more concerned with the process of results, attempt to describe systematically, factually and accurately about the facts in an area, the researcher acts as a key instrument, as well as data collectors. Instruments other than humans can also be used such as interview guides, observations, and field notes, as well as other tools such as photos, recordings and documents, but their function is limited to support the research task. 
as an instrument. Therefore, the presence of researchers in the field for qualitative research is absolutely necessary. Data collection techniques in this study were Quality Checklist on Full Day School management, student learning interest and teacher creativity at SMA As Syafi'iyah Medan, observation, interviews, documentation, and triangulation. Observational data collection techniques were used to find out all Full Day School management, student learning interests and teacher creativity at SMA As Syafi'iyah Medan. More clearly the data collection technique is presented in Figure below.

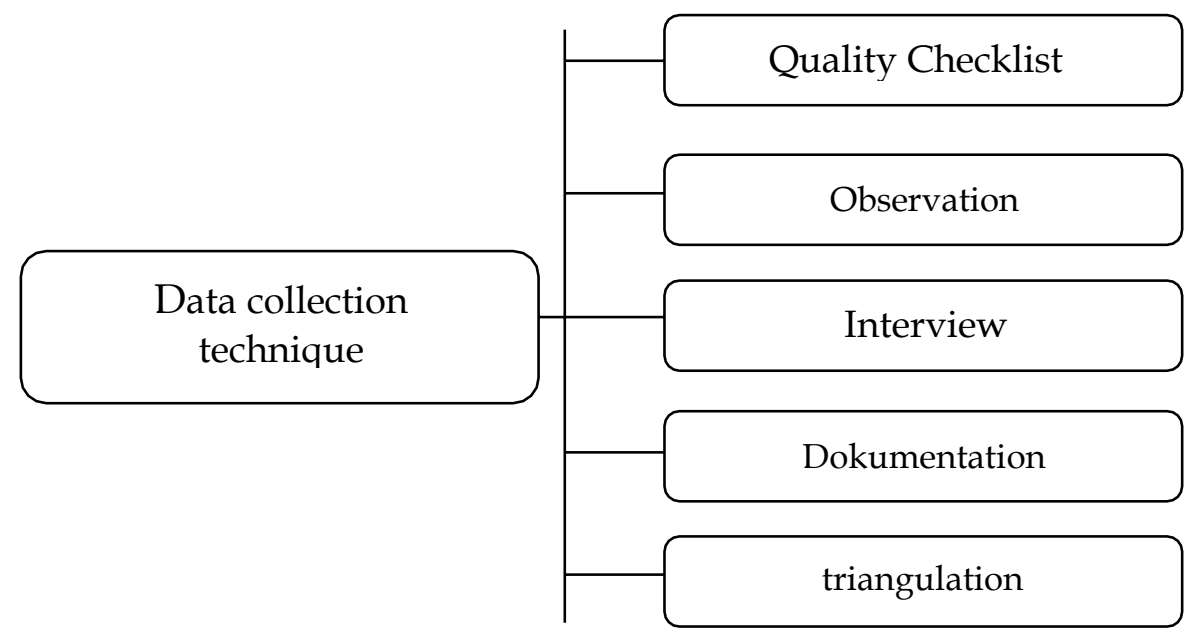

Figure 1. Data Collection Technique

Information mining will use data source retrieval techniques in a purposive way, namely data source retrieval techniques with certain methods. The data sources are determined by certain methods, one of which is interviews, in this study interviews were conducted with every teacher in the field of study. In addition to teachers, interviews were also conducted with students.

Checking the validity of the data in this study, it was carried out through the credibility check stage and with the following techniques:

\section{Persistent Observation}

In order to understand in-depth symptoms or events, repeated observations are made, obtain valid data (valid) from data sources by increasing the intensity of meetings with resource persons who are used as informants, and conducting research in reasonable conditions and at the right time.

\section{2. triangulation}

Check back the degree of confidence or information obtained by triangulation of sources and techniques. Triangulation was carried out covering 4 main things, namely data triangulation, research triangulation, theory triangulation and methodological triangulation. Through this inspection technique, it is believed that the facts, data and information can be accounted for and meet the requirements for the validity and reliability of the data found. 


\section{Member Check}

Peer discussions directly at the time of the interview and indirectly in the form of delivering a summary of the results of the interviews that have been written by the researcher. Member Check is the process of checking the data obtained by the researcher to the data provider, the purpose of this member check is to find out how far the data obtained is in accordance with what is given by the data provider.

\section{Result and Discussion}

\section{Full Day School Management at SMA As Syafi'iyah Medan}

Based on the results of observations and interviews with principals, homeroom teachers, students and guardians of students that the author conducted at SMA As Syafi'iyah Medan, it can be seen that the management process for the full day school program as an effort to improve character education for the 2019/2020 school year includes three stages, namely: planning full day school learning, implementation of full day school learning, and evaluation of full day school learning. Meanwhile, to improve the quality of education, especially by implementing management functions.

\section{Advantages of Full day School}

\section{Controlled Child Activities}

With the implementation of this system, the child will be in his school environment longer or always under the supervision of his teacher when carrying out activities, so that his activities can be more controlled than he is outside school.

\section{Habituation of Children in Worship}

As a religious country, of course, many activities are carried out every day as a means of strengthening their spiritual abilities, especially for Muslim children who can perform the Zuhur prayer in congregation, even adding tadarus and other religious activities.

\section{Language Application}

The longer time at school allows children to apply foreign languages (English, Arabic, Mandarin. This will really help his future to get along and learn more widely with international languages.

\section{Talent Development}

Every child has their own talents and interests, so it takes the right time and place to develop them, longer and varied school activities can channel the talents and interests of these children if they can be facilitated by the school.

\section{Group Study}

It often happens that children find it difficult when they have to do a task in groups, because of the problem of the distance between each house or the lack of means of transportation, with this system, children will easily gather if they have to be assigned to group work. 
6. Moral Cultivation

The moral or moral decline that is happening today can be reduced by learning and habituation of good morals in schools. But usually hindered by the problem of short time in school, so this system is deemed appropriate to overcome it.

\section{Love the Environment}

The application of love for the environment will be maximized by inviting children to equally care for and maintain their school environment with several activities that are useful for environmental sustainability. Every system must have a gap, especially if it is realized too late and cannot be overcome in the right way. So here are the disadvantages of the system this is what you might feel.

\section{Disadvantages of Full day School}

1. High Stress Level

Children will feel pressured and stressed because they are at school for too long, this will happen if the school is not able to provide the right portion of time, when to rest and when to do activities.

\section{Consumption at school}

Longer time certainly requires more consumption, this problem will definitely arise, especially for children with minimal economics to buy food at school. because the school does not have the allocation of funds for this problem.

\section{Time To Go to School}

In some areas, children travel long distances from home to school and even take several hours, so this system will be very difficult for them.

4. Costs to be spent

This system certainly requires more facilities and teaching staff, so of course it costs money to fulfill it.

\section{Lack of Teachers/Teachers}

As it is known that the unequal distribution of teacher allocations is the next problem, there are many schools that have very few teaching staff, so this system will also not work.

6. Lack of School Facilities

Let alone for carrying out additional activities such as sports and arts, for classroom buildings each school often faces problems. Then this system will certainly not work well 


\section{Discussion}

\section{Full day School Management}

The final series of important learning systems is the assessment (evaluation) of the success or failure of an education in achieving its goals, an assessment of the products produced can be carried out. Learning evaluation is a systematic and continuous process or activity to collect information about the process and learning outcomes of students in order to make decisions based on certain criteria and considerations.

\section{Efforts to Improve Student Character Education}

SMA As Syafi'iyah Medan in general in improving the character education of students in the full day school class by providing continuous guidance to students as an effort to improve student human resources, and SMA As Syafi'iyah Medan in determining completeness at least provides an assessment of three domains, namely the domain of cognitive, affective and psychomotor domains

\section{Efforts to Improve Student Education and Teacher Creativity in Fullday School Learning}

In managing the full day school program, it must have 10 main elements (Goetsch \& Davis, 1994) the components of integrated quality management (MMTP) as follows:

a. Focus on customer satisfaction, in MMTP both internal and external customers are driven. External customers determine the quality of graduates, while internal customers determine the quality, processes and environment associated with graduates.

b. Obsession with quality, in organizations that implement MMTP customers determine quality, with that quality the organization must be obsessed with fulfilling what customers want which means that all employees try to carry out every aspect of their work.

c. Scientific approach, this approach is needed, especially for designing work, in the decision-making process and problem solving related to the designed work.

d. Long-term commitment is very much needed in order to make cultural changes so that the implementation of MMTP can run well.

e. Teamwork, the MMTP organization applies teamwork, partnerships are forged and fostered, both between school members and outside the school.

f. Continuous improvement of the system, the existing system needs to be improved continuously so that the quality can increase.

g. Education and training, is a fundamental factor with the education and training of every teacher and administrative staff will improve their technical skills. The essence of education and training for teachers is to improve their skills and professionalism. 
h. Controlled freedom, involvement and empowerment of teachers and administrative staff in decision making and problem solving is very important because it can increase the sense of ownership and responsibility for the decisions made, and can enrich insight and views in a decision.

i. Unity of purpose, so that the MMTP can be implemented properly, the school must have a clear unity of purpose.

j. The involvement and empowerment of teachers and administrative staff, the involvement of teachers and administrative staff is important in the implementation of MMTP.

\section{Conclusion}

Based on the results of research and data analysis regarding "Management Full Day School at SMA As Syafi'iyah Medan" The author can conclude as follows;

Full Day School Management at SMA As Syafi'iyah Medan. As an effort to improve student character education at SMA As Syafi'iyah Medan includes stages, namely: planning full day school learning, implementing full day school learning and evaluating full day school learning. Learning planning is adjusted to the curriculum adopted by SMA As Syafi'iyah Medan, namely the government curriculum, local curriculum and school curriculum and preparation in the form of a syllabus and lesson plan. The implementation of full day school learning consists of habituation activities, exemplary activities, nationalism and patriotism activities as well as student creativity activities. Evaluation of full day school learning in general SMA As Syafi'iyah Medan in determining mastery at least provides an assessment of three domains, namely the cognitive, affective and psychomotor.

Efforts to Interest in Student Learning at SMA As Syafi'iyah Medan. By carrying out all components of integrated education quality management, effective teamwork with the principle of "teamwork" and effective leadership in accordance with integrated education quality management. In addition, by maximizing the supporting factors for learning in the classroom, namely having teachers as professional educators, the availability of teaching aids or learning media, the availability of adequate facilities and infrastructure and students' interest in learning.

\section{References}

Fahmi, A. (2019). Polarisasi Manajemen Strategik Pendidikan Dalam Implementasi Full Day School. Jurnal Visionary: Penelitian dan Pengembangan dibidang Administrasi Pendidikan, 4(1).

Ismail, I. (2016). Character education based on religious values: an Islamic perspective. Ta'dib: Jurnal Pendidikan Islam, 21(1), 41-58.

Khori, A. (2016). Manajemen strategik dan mutu pendidikan Islam. Manageria: Jurnal Manajemen Pendidikan Islam, 1(1), 75-99. 
Maya, R. (2017). Analisa Kebijakan Publik Konversi IAIN Menjadi UIN. Edukasi Islami: Jurnal Pendidikan Islam, 3(05).

Primarni, A. (2016). Pendidikan holistik: format baru pendidikan Islam membentuk karakter paripurna. Al Mawardi Prima.

Sari, W. I., Aliman, A., \& Djuwita, P. (2017). Strategi Kepala Sekolah dalam Meningkatkan Disiplin Guru. Manajer Pendidikan, 11(3).

Subaidi, S. (2014). Konsep Pendidikan Islam dengan Paradigma Humanis. Tarbawi: Jurnal Pendidikan Islam, 11(2).

Umam, M. K. (2017). Analisis Lingkungan Strategik Dalam Corak Penyelenggaraan Pendidikan Islam. Al-Hikmah: Jurnal Kependidikan Dan Syariah, 5(1), 1-8.

Wicaksono, A. G. (2018). Fenomena Full Day School dalam Sistem Pendidikan Indonesia. Jurnal Komunikasi Pendidikan, 1(1), 10-18.

Widiyanto, M. K. (2016). Strategi rekruitmen dan seleksi sumber daya insani untuk meningkatkan produktivitas kinerja karyawan pada KJKS BMT Al-Hikmah Ungaran (Doctoral dissertation, UIN Walisongo). 